\title{
Effects of immunonutrition on biomarkers in traumatic brain injury patients in Malaysia: a prospective randomized controlled trial
}

Vineya Rai Hakumat Rai ${ }^{1,2}$, Lee Fern Phang ${ }^{3}$, Sheau Fung Sia ${ }^{4}$, Amirah Amir $^{5^{*}}$ (D, Jeyaganesh S. Veerakumaran ${ }^{6}$, Mustafa Kassim Abdulazez Kassim ${ }^{6}$, Rafidah Othman ${ }^{7}$, Pei Chien Tah', Pui San Loh',

Mohamad Irfan Othman Jailani ${ }^{6}$ and Gracie Ong ${ }^{6}$

\begin{abstract}
Background: Head injury is one of the top three diagnosis leading to intensive care unit (ICU) admission in Malaysia. There has been growing interest in using immunonutrition as a mode of modulating the inflammatory response to injury or infection with the aim of improving clinical outcome. The aim of the present study was to evaluate the effect of an immunonutrition on biomarkers (IL-6, glutathione, CRP, total protein and albumin) in traumatic brain injury patients.
\end{abstract}

Methods: Thirty six patients with head injury admitted to neurosurgical ICU in University Malaya Medical Centre were recruited for this study, over a 6-month period from July 2014 to January 2015. Patients were randomized to receive either an immunonutrition (Group A) or a standard (Group B) enteral feed. Levels of biomarkers were measured at day 1, 5 and 7 of enteral feeding.

Results: Patients in Group A showed significant reduction of IL-6 at day $5(p<0.001)$ with concurrent rise in glutathione levels $(p=0.049)$. Patients in Group A also demonstrated a significant increase of total protein level at the end of the study (day 7).

Conclusion: These findings indicate the potential of immunonutrition reducing cytokines and increasing antioxidant indices in patients with TBI. However, further studies incorporating patient outcomes are needed to determine its overall clinical benefits.

Trial registration: National Medical Research Register (NMRR) ID: 14-1430-23,171. ClinicalTrials.gov identifier: NCT03166449.

Keywords: Biomarkers, Immunonutrition, Traumatic brain injury, Neomune, Enteral nutrition, Cytokines

\section{Background}

In 2014, injury ranked fifth as the most common cause of hospitalisation in Malaysia, with $86 \%$ of major trauma patients sustaining injuries to head and neck $[1,2]$. It is known that injuries to the brain is among the most likely to result in death and disability [3]. Therefore, it was unsurprising when the Malaysian Registry of Intensive

\footnotetext{
* Correspondence: amirahamir@ummc.edu.my

${ }^{5}$ Department of Parasitology, Faculty of Medicine, University of Malaya, 50603 Kuala Lumpur, Malaysia

Full list of author information is available at the end of the article
}

Care reported head injury as one of the top three diagnosis leading to intensive care unit (ICU) admissions with an in-hospital mortality rate of $22.1 \%$ [4]. In addition to causing a significant problem in Malaysia, injury related mortality and morbidity also affects countries worldwide and is expected to be a major cause of death and disability by the year 2030 [5].

Patients with traumatic brain injury (TBI) often develop a hypermetabolic state whereby there is an increase in energy expenditure [6-8]. Consequently, this led to clinicians acknowledging nutritional support as an essential 
component in managing critically ill patients [9]. A recent meta-analysis showed that early nutrition in patients sustaining TBI was associated with a significant reduction in mortality rate, lower risk of infectious complications and lower risk of poor outcome [10].

Due to its dynamic pathophysiology, the damage in TBI does not stop following the primary insult. A combination of systemic derangements (hypoxia, hypotension or hypercarbia) and local events (inflammation, oxidative stress and ion imbalance) often lead to secondary brain injury [11]. There has been growing interest in using immunonutrition as a mode of modulating the inflammatory response to injury or infection with the aim of improving clinical outcome $[12,13]$. Immune-enhancing or immunemodulation enteral formula has been shown to significantly reduce infection rate in TBI patients [10, 14-16]. In fact, a systemic review involving critically ill patients showed that the use of immune-modulating diets supplemented with fish oil improved the outcome of medical ICU patients (with SIRS/sepsis/ARDS) [17]. Omega-3 fatty acids namely docosahexaenoic acid (DHA) and eicosapentaenoic acid (EPA) found in fish oil are thought to play an important role in the repair and resolution of inflammation [18]. These two fatty acids also boost immune response by improving lymphocyte function [19]. Interestingly, research on DHA and EPA using animal model have shown favourable outcome in its neurorestorative capacities in TBI [20].

This study aims to evaluate the effect of a specific immunonutrition, Neomune, on biomarkers (cytokines, acute phase serum proteins and antioxidants) in traumatic brain injury patients. This immune enhancing enteral feed contains arginine, glutamine and omega- 3 fatty acid.

\section{Methods}

This study and its protocol was approved by the Medical Ethics Committee University Malaya Medical Center (MEC ID NO: 20,143-15). Written informed consent was obtained from patient's next of kin.

A prospective randomized controlled trial in patients with head injury comparing two high energy protein entera formula; Neomune (manufactured by Thai Otsuka Pharmaceutical Co., Ltd., Thailand) and Fresubin ${ }^{\circ}$ HP (manufactured by Fresenius Kabi, Bod Hamburg, Germany) was conducted. Fresubin ${ }^{\circ}$ HP energy is the standard enteral feeding used in neurosurgical ICU patients in University Malaya Medical Centre. Neomune was chosen to study its immune-modulating effects.

Patients receiving Neomune were classified as Group A $(n=18)$, whereas those receiving Fresubin ${ }^{\circ}$ HP energy as Group B $(n=18)$. Neomune is enriched with arginine, glutamine and omega-3 fatty acid. The composition of these two formulas are described in Table 1.

\section{Subject recruitment criteria}

Thirty six patients with head injury admitted to neurosurgical ICU, University Malaya Medical Centre were recruited for this study, over a 6-month period from July 2014 to January 2015. Patient's inclusion criteria were a) age between 15 and 78 years old, b) admission within $48 \mathrm{~h}$ of post traumatic event, c) moderate to severe head injury (Glasgow Coma Scale 3-12) and, d) requiring enteral nutrition. Exclusion criteria were a) history of uncontrolled diabetes mellitus, b) history of renal or liver dysfunction, c) severe sepsis with multi organ failure and d) history of significant abdominal or chest injuries requiring major surgery.

\section{Feeding protocol}

Eligible patients were randomized into receiving either Neomune (Group A) or Fresubin ${ }^{\circ}$ HP energy (Group B) using a computerized random number generator. Fresubin ${ }^{\circ} \mathrm{HP}$ energy is a premixed formula with an energy of $1.5 \mathrm{kcal} / \mathrm{ml}$. Neomune formula comes in powder form and thus was prepared to reach a concentration of $1.5 \mathrm{kcal} / \mathrm{ml}$ in order to make it comparable for the trial.

Enteral feeding was delivered within 24 to $48 \mathrm{~h}$ after admission or surgery according to Brain Trauma Foundation (BTF) Guidelines [21]. All feeding were introduced via nasogastric tube and carried out using infusion pump. Enteral feeding was commenced at an initial rate of $20 \mathrm{ml} / \mathrm{h}$, and increased by $20 \mathrm{ml} / \mathrm{h}$ every $6 \mathrm{~h}$ until target calorie was reached, provided that there was no significant gastric residual volume $(<300 \mathrm{~mL})$. The target calorie for each patient was determined by the clinician working alongside the dietitian using Harris Benedict equation which measures Resting Energy Expenditure (REE). This was further corrected $140 \%$ of REE based on studies done on traumatic brain injured patients $[22,23]$ and nutrition guidelines published by the BTF, the American Association of Neurological Surgeons, and the Joint Section on Neurotrauma and Critical Care [21]. Patients going for scheduled surgery are kept nil by mouth $6 \mathrm{~h}$ prior surgery. Feeding interruption are also kept to a minimal if patients are undergoing procedures, extubation or imaging.

\section{Data collection}

Venous blood was withdrawn from patients at day 1, 5 and 7 of enteral nutrition to measure the levels of interleukin-6 (IL-6), glutathione, C-reactive protein (CRP), total protein and albumin. The concentration of IL- 6 and glutathione were determined by ELISA (R\&D Systems, Minneapolis, USA) according to manufacturer's protocol. Prealbumin was not included as a nutritional biomarker in this study because this test is not available in our standard laboratory test. Furthermore, we were also limited by resource constraint. All measured outcomes were compared between Group A and Group B. 
Table 1 Composition of enteral formula

\begin{tabular}{lll}
\hline Formula & $\begin{array}{l}\text { Neomune } \\
(1.5 \mathrm{kcal} / \mathrm{mL})\end{array}$ & $\begin{array}{l}\text { Fresubin HP Energy } \\
(1.5 \mathrm{kcal} / \mathrm{mL})\end{array}$ \\
\hline Classification & Immune-enriched, lactose and gluten free & $\begin{array}{l}\text { High energy protein with medium chain triglyceride } \\
(\mathrm{MCT}) \text {, fibre free, lactose and gluten free }\end{array}$ \\
Total Energy & $1503 \mathrm{kcal}$ & $1502 \mathrm{kcal}$ \\
Carbohydrate & $187.5 \mathrm{~g} / \mathrm{L}=750 \mathrm{kcal}(50 \%)$ & $170 \mathrm{~g} / \mathrm{L}=680 \mathrm{kcal}(45 \%)$ \\
Protein & $93.75 \mathrm{~g} / \mathrm{L}=375 \mathrm{kcal}(25 \%)$ & $75 \mathrm{~g} / \mathrm{L}=300 \mathrm{kcal}(20 \%)$ \\
Fat & $42.0 \mathrm{~g} / \mathrm{L}=378 \mathrm{kcal} / \mathrm{L}(25 \%)$ & $58 \mathrm{~g} / \mathrm{L}=533 \mathrm{kcal}(35 \%)$ \\
Protein source (\%) & Casein $70 \%$ & Casein $>90 \%$ \\
& Arginine $20 \%$ & \\
Fat source (\%) & Glutamine $10 \%$ & MCT oil $57 \%$ \\
& Corn oil $30 \%$ & Fish oil $0.86 \%$ \\
NPC: N & Fish oil $20 \%$ & \\
\hline
\end{tabular}

\section{Sample size analysis}

The sample size for this study was calculated based on a similar study done previously on immune enhancing nutrition in traumatic brain injury by Painter et al. [24]. The following formula was applied:

$$
\boldsymbol{n}=\frac{2 \boldsymbol{\sigma}^{2}\left(\frac{Z \boldsymbol{\alpha}}{2}+\boldsymbol{Z} \boldsymbol{\beta}\right)^{2}}{\Delta^{2}}
$$

where $n$ is the required sample size. The symbol $\sigma$ represents the standard deviation of the outcome variable. Painter et al., found that the mortality rate for patients receiving immune enhancing nutrition formula in TBI was $7.5 \%(0.075)$ and thus, this value was used as $\sigma$ in the above calculation [24]. $\Delta$ symbolizes the effect size, $\mathrm{Z} \alpha / 2$ represents the desired level of statistical significance whereas $Z \beta$ represents the desired power. In this study, we determined our effect size as 0.05 as the standard value for detectable difference, confidence interval as $95 \%(Z \alpha / 2=1.96)$ and power of $80 \%(Z \beta=0.84)$. The final sample size obtained was 35.28. A total number of 36 patients were used in this study.

\section{Statistical analysis}

The data were analysed using SPSS (Statistical Package for the Social Sciences) software version 20.0. Paired t-test was used to compare the concentration of cytokines, acute phase serum proteins and antioxidants between day 1, 5 and 7 after the administration of enteral feeding. Independent sample t-test was used to compare continuous data which include cytokines, acute phase serum proteins and antioxidant levels between Group A and Group B. Statistical significance was predetermined at $p<0.05$.

\section{Results}

Demographic and clinical characteristics

Demographic and clinical characteristics were obtained from all 36 patients as displayed in Table 2. Mean age in Group A and Group B was $42 \pm 70$ (range: 15-75) and $32 \pm 50$ (range: $15-56$ ) years old respectively, with male predominating in both groups. The main cause of brain injury in this study were a consequence of motor-vehicle accident, with more than half of patients in each group being admitted with severe Glasgow Coma scale (GCS) score $(<8)$. There were no significant differences between Group A and Group B with respect to demographic data, GCS scoring, diagnosis and clinical interventions.

\section{Effects of immunonutrition on cytokines, acute phase serum proteins and antioxidants indices}

Observation in group A from day 1 to 7 showed a downward trend of IL-6 concentration (Table 3). This reduction was significant at day 5 and 7 (Table 4). On the other hand, glutathione and total protein concentration increased from day 1 to 7 which reached significance at day 5 and 7 respectively (Tables 3 and 4). Although there were changes in cytokines, acute phase serum proteins and antioxidants indices in Group B throughout the study, its trend were not consistent and none of the changes were significant.

Comparison between both groups revealed significantly lower IL-6 levels at day 7 of receiving enteral feeding in Group A (Table 3). Additionally, glutathione levels in group A at day 5 and 7 were significantly higher compared to Group B (Table 3).

\section{Discussion}

Protein requirements in trauma patients are proportionately higher and thus are not met by provision of routine 
Table 2 Demographic profile and clinical data of patients in Group A and B

\begin{tabular}{|c|c|c|c|}
\hline \multirow[t]{3}{*}{ Parameter } & \multicolumn{2}{|c|}{ Enteral feed } & \multirow[t]{3}{*}{$p$ value } \\
\hline & Group A & Group B & \\
\hline & $(n=18)$ & $(n=18)$ & \\
\hline Gender (\%): & & & 0.560 \\
\hline Male & 94.4 & 88.9 & \\
\hline Female & 5.6 & 11.1 & \\
\hline Age [mean] (years) & 42 & 32 & 0.067 \\
\hline Weight [mean] (kg) & 68.4 & 70.6 & 0.533 \\
\hline Mode of injury (\%): & & & 0.445 \\
\hline Motor-vehicle accident & 66.7 & 83.3 & \\
\hline Fall & 27.8 & 11.1 & \\
\hline Assault & 5.6 & 5.6 & \\
\hline Diagnosis (\%): & & & 0.972 \\
\hline Subarachnoid haemorrhage & 16.7 & 22.2 & \\
\hline Subdural haemorrhage & 33.3 & 27.8 & \\
\hline Extradural haemorrhage & 16.7 & 16.7 & \\
\hline Mixed haemorrhage & 33.2 & 33.3 & \\
\hline Glasgow Coma Score (\%) & & & 0.278 \\
\hline Minor & 0 & 0 & \\
\hline Moderate & 22.2 & 38.9 & \\
\hline Severe & 77.8 & 61.1 & \\
\hline Type of surgery (\%): & & & 0.409 \\
\hline Craniotomy & 5.6 & 11.1 & \\
\hline Craniectomy & 22.2 & 11.1 & \\
\hline Ventriculostomy & 38.9 & 61.1 & \\
\hline Conservative & 33.3 & 16.7 & \\
\hline
\end{tabular}

enteral formula [25]. The appropriate and safe level in the critically ill or hypermetabolic patient in which a pro-inflammatory state exists is much more difficult to determine. Therefore, the enteral formulas used in this study are both of high protein content to meet the BTF recommendation of providing a formula containing at least $15 \%$ of calories as protein [21].

This study showed that patients receiving Neomune, an immunonutrition, had significant reduction in their IL-6 levels compared to patients in Group B. Similar observations were reported when immunonutrition was administered to patients with TBI, patients undergoing major hepatobiliary resection and patients with gastrointestinal cancer $[16,26,27]$. Following TBI, IL-6, a key regulator of the inflammatory response, rises in brain tissue [28], cerebrospinal fluid and serum [29]. This cytokine plays a dual opposing role as it is associated with both pro and antiinflammatory effects [30]. Previous research on TBI serum IL-6 have shown contradicting findings. Kalabalikis et al. reported that there was no association between IL-6 levels with neurological outcome [31]. Whereas, others have
Table 3 The mean of cytokines, acute phase serum proteins and antioxidants concentrations at day 1,5 and 7

\begin{tabular}{|c|c|c|c|}
\hline \multirow[t]{2}{*}{ Parameters } & Group A & Group B & \multirow[t]{2}{*}{$p$-value } \\
\hline & Mean (SD) & Mean (SD) & \\
\hline \multicolumn{4}{|l|}{$\mathrm{IL}-6$ (pg/mL) } \\
\hline Day 1 & $113.10(81.140)$ & $101.90(76.163)$ & 0.753 \\
\hline Day 5 & $62.10(69.141)$ & $89.58(80.487)$ & 0.248 \\
\hline Day 7 & 42.18 (39.833) & 106.50 (92.992) & $0.004 *$ \\
\hline \multicolumn{4}{|c|}{ Glutathione $(\mu \mathrm{mol} / \mathrm{L})$} \\
\hline Day 1 & $182.00(100.796)$ & 144.70 (92.958) & 0.211 \\
\hline Day 5 & $245.60(134.536)$ & $141.60(55.924)$ & $0.009^{*}$ \\
\hline Day 7 & $270.10(155.392)$ & $125.20(79.603)$ & $0.011^{*}$ \\
\hline \multicolumn{4}{|l|}{$\mathrm{CRP}(\mathrm{mg} / \mathrm{dL})$} \\
\hline Day 1 & $10.42(4.682)$ & $10.96(6.143)$ & 0.994 \\
\hline Day 5 & $10.32(9.348)$ & $12.40(9.001)$ & 0.368 \\
\hline Day 7 & $8.31(9.264)$ & $11.74(7.425)$ & 0.109 \\
\hline \multicolumn{4}{|c|}{ Albumin $(g / L)$} \\
\hline Day 1 & $32.44(5.469)$ & $34.44(6.090)$ & 0.303 \\
\hline Day 5 & $34.06(6.743)$ & $33.67(4.325)$ & 0.981 \\
\hline Day 7 & $35.11(7.053)$ & $33.11(5.529)$ & 0.355 \\
\hline \multicolumn{4}{|c|}{ Total protein (g/L) } \\
\hline Day 1 & $57.17(7.755)$ & $59.11(9.424)$ & 0.536 \\
\hline Day 5 & $62.50(9.599)$ & $60.50(5.205)$ & 0.505 \\
\hline Day 7 & 65.89 (9.875) & $62.50(7.778)$ & 0.232 \\
\hline
\end{tabular}

demonstrated that high IL-6 level is correlated with poor outcome [32, 33]. For this reason, some authors have suggested reducing inflammatory mediators as a therapeutic strategy for TBI $[34,35]$. An animal study showed that the presence of IL- 6 may be beneficial during early stages of TBI and therefore, suggested that a timely, targeted approach is recommended in improving outcomes following TBI [36]. Another study involving animals with mild TBI showed that the neutralization of IL-6 resulted in restoration of normal motor coordination and it also mitigates the adverse effects of hypoxia which include exacerbated brain inflammation and injury [37]. Although subject to further studies, we postulate that the outcome from the use of immunomodulation in TBI can be extrapolated to humans and this concept can be exploited using immunonutrition to lower IL-6 levels in order to prevent secondary brain injuries.

This present study also demonstrated a significant increase of glutathione levels in patients receiving Neomune. Since glutamine is an important substrate for glutathione, depletions in glutamine will be reflected by glutathione reduction [38, 39]. In patients experiencing physiological stress, the synthesis of glutamine, a nonessential amino acid is unable to cater to the increased 
Table 4 The mean difference of cytokines, acute phase serum proteins and antioxidants concentrations between day 1,5 and 7

\begin{tabular}{|c|c|c|c|c|}
\hline \multirow[t]{2}{*}{ Parameters } & \multicolumn{2}{|l|}{ Group A } & \multicolumn{2}{|l|}{ Group B } \\
\hline & $\begin{array}{l}\text { Mean difference } \\
\text { (SEM) }\end{array}$ & $\overline{p \text {-value }}$ & $\begin{array}{l}\text { Mean difference } \\
\text { (SEM) }\end{array}$ & $\overline{p \text {-value }}$ \\
\hline \multicolumn{5}{|l|}{ IL-6 (pg/mL) } \\
\hline Day 1-5 & 48.49 (10.68) & $<0.001^{*}$ & $10.68(17.78)$ & 0.556 \\
\hline Day 5-7 & $0.22(14.29)$ & 0.988 & $27.19(20.48)$ & 0.214 \\
\hline Day 1-7 & $46.73(19.29)$ & $0.034^{*}$ & $12.55(34.14)$ & 0.722 \\
\hline \multicolumn{5}{|c|}{ Total Glutathione $(\mu \mathrm{mol} / \mathrm{L})$} \\
\hline Day 1-5 & $63.58(29.98)$ & $0.049^{*}$ & $3.16(18.33)$ & 0.865 \\
\hline Day 5-7 & $24.29(21.05)$ & 0.269 & $14.08(22.13)$ & 0.538 \\
\hline Day 1-7 & $83.41(39.27)$ & 0.053 & $2.56(30.00)$ & 0.934 \\
\hline \multicolumn{5}{|l|}{ CRP $(\mathrm{mg} / \mathrm{dL})$} \\
\hline Day 1-5 & $1.1(2.81)$ & 0.701 & $2.39(3.18)$ & 0.467 \\
\hline Day 5-7 & $1.74(1.43)$ & 0.240 & $2.06(1.74)$ & 0.257 \\
\hline Day 1-7 & $2.47(2.98)$ & 0.420 & $1.81(3.26)$ & 0.590 \\
\hline \multicolumn{5}{|c|}{ Albumin (g/L) } \\
\hline Day 1-5 & $1.61(1.71)$ & 0.359 & $0.78(1.30)$ & 0.558 \\
\hline Day 5-7 & $1.06(1.11)$ & 0.355 & $0.56(1.19)$ & 0.645 \\
\hline Day 1-7 & $2.67(2.03)$ & 0.207 & $1.33(1.52)$ & 0.391 \\
\hline \multicolumn{5}{|c|}{ Total protein $(\mathrm{g} / \mathrm{L})$} \\
\hline Day 1-5 & $5.33(2.93)$ & 0.087 & $1.39(2.20)$ & 0.537 \\
\hline Day 5-7 & $3.39(2.05)$ & 0.117 & $2.00(1.82)$ & 0.286 \\
\hline Day 1-7 & $8.72(3.26)$ & $0.016^{*}$ & $3.39(2.25)$ & 0.151 \\
\hline
\end{tabular}

${ }^{*} p$-value $<0.05$

glutamine requirement [40]. Furthermore, patients with brain injury have been observed to experience profound hypoglutaminemia [41-44]. Glutathione has important function as anti-oxidant as it is a scavenger for reactive oxygen species [17]. During the acute ischemic phase of TBI, a hypermetabolic state leads to hyperglycaemia and intracellular lactate production which is associated with the development of reactive oxygen species [45-48]. Thus, tissues depleted of glutathione may undergo oxidative stress leading to complications such as predisposing patients to bacterial translocation and recurrent sepsis [49, 50]. Glutamine supplementation has been associated with lower mortality rates, shorter hospital stay and decreased occurrence of pneumonia and stress ulcer [51].

Patients receiving Neomune demonstrated a significant increase of total protein level at the end of the study whereas no significant change was seen in albumin level throughout the study. Although serum protein and albumin were previously suggested as biomarkers for malnutrition [52], serum albumin is not well correlated to protein mass [53] and does not always significantly increase following nutritional programmes [54]. Whilst albumin and protein level may be useful in the assessment of malnutrition [53], these biomarkers are not helpful at monitoring potential therapeutic effects of nutrition [55].

Immunonutrition came into existence as part of an immune-modulating strategy to improve patient outcome in the critically ill. Many clinical trials, metaanalyses and systemic reviews have been done on the use of immunonutrition in diversed population with inconsistent outcomes [56]. One review on the use of immunonutrition showed that it may reduce infectious complications in trauma and perioperative patients [57], whereas another meta-analyses revealed no effect of immune modulating diets on mortality or length of stay [17]. Other systematic reviews looking at the efficacy of immunonutrition in the critically ill generally concluded that the incidence of infection and hospital length of stay are reduced, with no reduction in mortality $[56,58,59]$. Additionally, another meta-analysis showed that glutamine and selenium supplementation may result in reduction of nosocomial infections among the critically ill [60]. Although it is postulated that immunonutrition influence immune parameters and has anti-inflammatory effects, it is has not always been associated with better clinical outcomes. Some researchers propose that immunonutrition may be harmful in some subgroups of critically ill patients [55]. Rathmacher et al. found that blood urea was raised in patients receiving immunonutrition and attributed this to the combination of increased nitrogen load and the specific effect of arginine and glutamine in stimulating ureagenesis [61]. As such, careful assessment may be needed in patients with kidney and liver disease before immunonutrition can be prescribed. There is an emerging paradigm shift to move from immunonutrition to pharmaconutrition, where effect of individual immunonutrients are assessed independent of standard nutritional support [62]. The way forward is to design future studies similar to drug trials, which include evaluating clinically relevant outcome in a well-defined population [63].

Interestingly, immunomodulators have also been used in combination with antimicrobial therapy in clinical trials in search of new strategies for the treatment of bacterial infections [64]. Unfortunately, the use of immunonutritian was found not to be encouraging the antimicrobial therapy in bacterial infections [65-67]. However, this is an intelligent use of immunomodulators and this idea can be explored to look at other usage of immunonutrition.

This study has some limitations which have to be pointed out. Due to resource constraint, other cytokines indices such as tumour necrosis factor, IL-1, IL-8 and IL-10 were not measured. Confounding factors that may affect biomarker levels such as sepsis was also not included during data collection. Since patients' overall progress and outcome were not looked into in this study, no definite correlation can be made between immunonutrition and patient outcome. 


\section{Conclusions}

The present study showed that IL-6 levels were significantly reduced whereas glutathione levels were significantly higher following feeding with Neomune, an immunonutrition. These findings indicate the potential of immunonutrition reducing cytokines and increasing antioxidant indices in patients with TBI. However, further studies incorporating patient outcomes are needed to determine its overall clinical benefits.

\section{Abbreviation}

ARDS: Acute respiratory distress syndrome; ICU: Intensive care unit; SIRS: Systemic inflammatory response syndrome; TBI: Traumatic brain injury

\section{Acknowledgements}

Not applicable.

\section{Funding}

This work was supported by the University of Malaya Research Grant (P00102014A) and Fundamental Research Grant Scheme initiative (FP019-2013B).

\section{Availability of data and materials}

The datasets collected and/or analyzed during the current study are available from the corresponding author upon reasonable request.

\section{Authors' contributions}

VRHR, GO, LFP, SFS developed and supervised the study. LFP, JSV, PSL, PCT and $\mathrm{RO}$ coordinated the study, recruited subjects and gathered informed consent. AA, MKAK and MIOJ interpreted, analysed the data and performed statistical analyses. AA wrote the first draft. AA, VRHR, PCT, PSL and MIOJ revised subsequent drafts of the manuscript and performed additional statistical analyses. All authors have read and approved of the final manuscript.

\section{Competing interest}

The authors declare that they have no competing interests.

\section{Consent for publication}

Not applicable.

\section{Ethical approval and consent to participate}

This study and its protocol was approved by the Medical Ethics Committee University Malaya Medical Center (MEC ID NO: 20,143-15). Written informed consent was obtained from patient's next of kin.

\section{Publisher's Note}

Springer Nature remains neutral with regard to jurisdictional claims in published maps and institutional affiliations.

\section{Author details \\ ${ }^{1}$ School of Medicine, Taylor's University, Lakeside Campus, 47500 Subang Jaya, Malaysia. ${ }^{2}$ KPJ Tawakkal Specialist Hospital, Jalan Pahang Barat, 53000 Kuala Lumpur, Malaysia. ${ }^{3}$ Department of Anaesthesiology, Hospital Umum Sarawak, Jalan Hospital, 93586 Kuching, Sarawak, Malaysia. ${ }^{4}$ Division of Neurosurgery, Faculty of Medicine, University of Malaya, 50603 Kuala Lumpur, Malaysia. ${ }^{5}$ Department of Parasitology, Faculty of Medicine, University of Malaya, 50603 Kuala Lumpur, Malaysia. ${ }^{6}$ Department of Anaesthesiology, Faculty of Medicine, University Malaya, 50603 Kuala Lumpur, Malaysia. ${ }^{7}$ Department of Dietetics, University Malaya Medical Centre, 50603 Kuala Lumpur, Malaysia.}

Received: 17 November 2016 Accepted: 31 May 2017 Published online: 15 June 2017

\section{References}

1. MOH: National trauma database January 2009 to December 2009 fourth report. 2011
2. Health Facts 2015 [http://vlib.moh.gov.my/cms/documentstorage/com.tms. cms.document.Document_2e8efe25-a0188549-d5315d00-e9ca9560/KKM HEALTH_FACTS_2015.pdf].

3. Hyder AA, Wunderlich CA, Puvanachandra P, Gururaj G, Kobusingye OC. The impact of traumatic brain injuries: a global perspective. NeuroRehabilitation. 2007:22(5):341-53.

4. MOH: Malaysian registry of intensive care report for 2013. Malaysian Registry of Intensive Care, Clinical Research Centre, Ministry of Health Malaysia. 2013. http://www.moh.gov.my/index.php/file_manager/dl_item/554756755a584a $696158526862693942626 d 567 a 6447567 a 6157397362326470494752686269$ $4253595864686447467549464 a 6863476$

5. Mathers CD, Loncar D. Projections of global mortality and burden of disease from 2002 to 2030. PLoS Med. 2006:3(11):e442.

6. Clifton GL, Robertson CS, Grossman RG, Hodge S, Foltz R, Garza C. The metabolic response to severe head injury. J Neurosurg. 1984;60(4):687-96.

7. Clifton GL, Robertson CS, Choi SC. Assessment of nutritional requirements of head-injured patients. J Neurosurg. 1986;64(6):895-901.

8. Young B, Ott L, Norton J, Tibbs P, Rapp R, McClain C, et al. Metabolic and nutritional sequelae in the non-steroid treated head injury patient. Neurosurgery. 1985;17(5):784-91.

9. Alberda C, Gramlich L, Jones N, Jeejeebhoy K, Day AG, Dhaliwal R, et al. The relationship between nutritional intake and clinical outcomes in critically ill patients: results of an international multicenter observational study. Intensive Care Med. 2009;35(10):1728-37.

10. Wang X, Dong Y, Han X, Qi XQ, Huang CG, Hou LJ. Nutritional support for patients sustaining traumatic brain injury: a systematic review and metaanalysis of prospective studies. PLoS One. 2013;8(3):e58838.

11. Rosenfeld JV, Maas Al, Bragge P, Morganti-Kossmann MC, Manley GT, Gruen RL. Early management of severe traumatic brain injury. Lancet. 2012:380(9847):1088-98.

12. Grimble R. Nutritional modulation of immune function. Proc Nutr Soc. 2001; 60(03):389-97.

13. Peterik A, Milbrandt EB, Darby JM. Immunonutrition in critical illness: stil fishing for the truth. Crit Care. 2009;13(3):1-3.

14. De Arruda ISF, de Aguilar-Nascimento JE. Benefits of early enteral nutrition with glutamine and probiotics in brain injury patients. Clin Sci. 2004;106(3):287-92.

15. Briassoulis G, Filippou O, Kanariou M, Papassotiriou I, Hatzis T. Temporal nutritional and inflammatory changes in children with severe head injury fed a regular or an immune-enhancing diet: a randomized, controlled trial. Pediatr Crit Care Med. 2006;7(1):56-62.

16. Khorana J, Rerkasem K, Apichartpiyakul C, Sakonwasun C, Watcharasalcslip W, Waniyapong T, et al. Immunonutrition and cytokine response in patients with head injury. J Med Assoc Thail. 2009;92(2):188.

17. Marik PE, Zaloga GP. Immunonutrition in critically ill patients: a systematic review and analysis of the literature. Intensive Care Med. 2008;34(11):1980-90

18. Serhan CN, Chiang N, Van Dyke TE. Resolving inflammation: dual antiinflammatory and pro-resolution lipid mediators. Nat Rev Immunol. 2008;8(5):349-61.

19. Calder PC. n-3 Polyunsaturated fatty acids, inflammation, and inflammatory diseases. Am J Clin Nutr. 2006;83:S1505-19.

20. Hasadsri L, Wang BH, Lee JV, Erdman JW, Llano DA, Barbey AK, et al. Omega-3 fatty acids as a putative treatment for traumatic brain injury. J Neurotrauma. 2013:30(11):897-906.

21. Bullock MR, Povlishock JT. Guidelines for the management of severe traumatic brain injury. Editor's Commentary. J Neurotrauma. 2007;24(Supp 1):2. p preceding S1

22. Harris JA, Benedict FG. A biometric study of human basal metabolism. Proc Natl Acad Sci. 1918;4(12):370-3.

23. Roza AM, Shizgal HM. The Harris Benedict equation reevaluated: resting energy requirements and the body cell mass. Am J Clin Nutr. 1984;40(1):168-82

24. Painter TJ, Rickerds J, Alban RF. Immune enhancing nutrition in traumatic brain injury-A preliminary study. Int J Surg. 2015;21:70-4

25. McClave SA, Martindale RG, Vanek WW, McCarthy M, Roberts P, Taylor B, et al. Guidelines for the provision and assessment of nutrition support therapy in the adult critically ill patient: Society of Critical Care Medicine (SCCM) and American Society for Parenteral and Enteral Nutrition (ASPEN). J Parenter Enter Nutr. 2009:33(3):277-316.

26. Wu GH, Zhang YW, Wu ZH. Modulation of postoperative immune and inflammatory response by immune-enhancing enteral diet in gastrointestinal cancer patients. World J Gastroenterol. 2001;7(3):357-62. 
27. Uno H, Furukawa K, Suzuki D, Shimizu H, Ohtsuka M, Kato A, et al. Immunonutrition suppresses acute inflammatory responses through modulation of resolvin E1 in patients undergoing major hepatobiliary resection. Surgery. 2016;

28. Frugier T, Morganti-Kossmann MC, O'Reilly D, McLean CA. In situ detection of inflammatory mediators in post mortem human brain tissue after traumatic injury. J Neurotrauma. 2010;27(3):497-507.

29. Kossmann $\mathrm{T}$, Hans VH, Imhof HG, Stocker R, Grob P, Trentz O, et al. Intrathecal and serum interleukin- 6 and the acute-phase response in patients with severe traumatic brain injuries. Shock. 1995;4(5):311-7.

30. Lenzlinger PM, Morganti-Kossmann M-C, Laurer HL, Mclntosh TK. The duality of the inflammatory response to traumatic brain injury. Mol Neurobiol. 2001;24(1-3):169-81.

31. Kalabalikis P, Papazoglou K, Gouriotis D, Papadopoulos N, Kardara M, Papageorgiou F, et al. Correlation between serum IL-6 and CRP levels and severity of head injury in children. Intensive Care Med. 1999;25(3):288-92.

32. Arand M, Melzner H, Kinzl L, Bruckner UB, Gebhard F. Early inflammatory mediator response following isolated traumatic brain injury and other major trauma in humans. Langenbeck's Arch Surg. 2001;386:241-8.

33. Woiciechowsky C, Schoning B, Cobanov J, Lanksch WR, Volk HD, Docke WD. Early IL-6 plasma concentrations correlate with severity of brain injury and pneumonia in brain-injured patients. J Trauma. 2002;5:339-45.

34. Lloyd E, Somera-Molina K, Van Eldik LJ, Watterson DM, Wainwright MS. Suppression of acute proinflammatory cytokine and chemokine upregulation by post-injury administration of a novel small molecule improves long-term neurologic outcome in a mouse model of traumatic brain injury. J Neuroinflammation. 2008;5(1):28.

35. Bracken MB. CRASH (corticosteroid randomization after significant head injury trial): landmark and storm warning. Neurosurgery. 2005;57(6):1300-2.

36. Ley EJ, Clond MA, Singer MB, Shouhed D, Salim A. IL6 deficiency affects function after traumatic brain injury. J Surg Res. 2011;170(2):253-6.

37. Yang SH, Gangidine M, Pritts TA, Goodman MD, Lentsch AB. Interleukin 6 mediates neuroinflammation and motor coordination deficits after mild traumatic brain injury and brief hypoxia in mice. Shock. 2013;40(6):471.

38. Marik PE. Arginine: too much of a good thing may be bad! Crit Care Med. 2006:34(11):2844-7.

39. Flaring UB, Rooyackers OE, Wernerman J, Hammarqvist F. Glutamine attenuates post-traumatic glutathione depletion in human muscle. Clin Sc (Lond). 2003;104(3):275-82.

40. Adesanya TA, Sullivan RC, Stawicki SP, Evans DC. Nutrition in Traumatic Brain Injury: Focus on the Immune Modulating Supplements. 2014.

41. Petersen SR, Jeevanandam M, Holaday NJ, Lubhan CL. Arterial-jugular vein free amino acid levels in patients with head injuries: important role of glutamine in cerebral nitrogen metabolism. J Trauma. 1996;41(4):687-94. discussion 694-685

42. Platt SR. The role of glutamate in central nervous system health and disease-a review. Vet J. 2007;173(2):278-86,

43. van Landeghem FK, Weiss T, Oehmichen M, von Deimling A. Decreased expression of glutamate transporters in astrocytes after human traumatic brain injury. J Neurotrauma. 2006;23(10):1518-28.

44. Zlotnik A, Gurevich B, Tkachov S, Maoz I, Shapira Y, Teichberg VI. Brain neuroprotection by scavenging blood glutamate. Exp Neurol. 2007;203(1):213-20.

45. Cook AM, Peppard A, Magnuson B. Nutrition considerations in traumatic brain injury. Nutr Clin Pract. 2008;23(6):608-20.

46. Fruin $\mathrm{AH}$, Taylon $\mathrm{C}$, Pettis MS. Caloric requirements in patients with severe head injuries. Surg Neurol. 1986;25(1):25-8.

47. Li P-A, Liu G-J, He QP, Floyd RA, Siesjö BK. Production of hydroxyl free radical by brain tissues in hyperglycemic rats subjected to transient forebrain ischemia. Free Radic Biol Med. 1999:27(9):1033-40.

48. Diaz-Parejo P, Ståhl N, Xu W, Reinstrup P, Ungerstedt U, Nordström C-H. Cerebral energy metabolism during transient hyperglycemia in patients with severe brain trauma. Intensive Care Med. 2003;29(4):544-50.

49. O'Dwyer ST, Smith RJ, Hwang TL, Wilmore DW. Maintenance of small bowel mucosa with glutamine-enriched parenteral nutrition. J Parenter Enter Nutr. 1989;13(6):579-85.

50. Houdijk AP, Van Leeuwen PA, Boermeester MA, Van Lambalgen T, Teerlink T, Flinkerbusch EL, et al. Glutamine-enriched enteral diet increases splanchnic blood flow in the rat. Am J Phys. 1994;267(6 Pt 1):G1035-40.

51. Yang DL, Xu JF. Effect of dipeptide of glutamine and alanine on severe traumatic brain injury. Chin J Traumatol. 2007;10(3):145-9.
52. Marik PE, Zaloga GP. Immunonutrition in High-Risk surgical patients a systematic review and analysis of the literature. J Parenter Enter Nutr. 2010;34(4):378-86.

53. Forget $P$, Echeverria G, Giglioli S, Bertrand B, Nikis S, Lechat J-P, De Kock M. Biomarkers in immunonutrition programme, is there still a need for new ones? A brief review. Ecancermedicalscience. 2015;9:546.

54. Aussel C, Cynober L. Is serum albumin a marker of nutritional status? Nutr Clin Metab. 2013:27(1):28-33.

55. Heyland DK, Novak F, Drover JW, Jain M, Su X, Suchner U. Should immunonutrition become routine in critically ill patients? A systematic review of the evidence. JAMA. 2001;286(8):944-53.

56. Roehl K. Immunonutrition in 2016: Benefit, Harm or Neither? Pract Gastroenterol. 2016:154:27.

57. McCowen KC, Bistrian BR. Immunonutrition: problematic or problem solving? Am J Clin Nutr. 2003:77(4):764-70.

58. Beale RJ, Bryg DJ, Bihari DJ. Immunonutrition in the critically ill: a systematic review of clinical outcome. Crit Care Med. 1999;27(12):2799-805.

59. Montejo JC, Zarazaga A, López-Martínez J, Urrútia G, Roqué M, Blesa AL, et al. Immunonutrition in the intensive care unit. A systematic review and consensus statement. Clin Nutr. 2003;22(3):221-33.

60. Chen $\mathrm{QH}$, Yang Y, He HL, Xie JF, Cai SX, Liu AR, et al. The effect of glutamine therapy on outcomes in critically ill patients: a meta-analysis of randomized controlled trials. Crit Care. 2014;18(1):R8.

61. Rathmacher JA, Nissen S, Panton L, Clark RH, May PE, Barber AE, et al. Supplementation with a combination of $\beta$-hydroxy- $\beta$-methylbutyrate(HMB), arginine, and glutamine is safe and could improve hematological parameters. J Parenter Enter Nutr. 2003;28:65-75.

62. Heyland D, Dhaliwal R. Immunonutrition in the critically ill: from old approaches to new paradigms. Intensive Care Med. 2005;31:501-3.

63. Jones NE, Heyland DK. Pharmaconutrition: a new emerging paradigm. Curr Opin Gastroenterol. 2008;24:215-22.

64. Sparo M, Sanchez Bruni SF. Approach to optimise the treatment of bacterial infections: combined antimicrobial therapy with enhancers of innate immunity. Clin Exp Pharmacol. 2012;2:e106.

65. Vincent JL. Search for effective immunomodulating strategies against sepsis. Lancet. 1998;351(9107):922-3.

66. Dellinger RP. Severe sepsis trials: why have they failed? Minerva Anestsesiol. 1999;65(6):340-5.

67. Cohen J. Adjunctive therapy in sepsis: a critical analysis of the clinical trial programme. Br Med Bull. 1999;55(1):212-25.

\section{Submit your next manuscript to BioMed Central and we will help you at every step:}

- We accept pre-submission inquiries

- Our selector tool helps you to find the most relevant journal

- We provide round the clock customer support

- Convenient online submission

- Thorough peer review

- Inclusion in PubMed and all major indexing services

- Maximum visibility for your research

Submit your manuscript at www.biomedcentral.com/submit
) Biomed Central 